\title{
Correction to: A paraneoplastic limbic encephalitis from an anorectal small cell neuroendocrine carcinoma: a case report
}

\author{
Raffaele Longo ${ }^{1 *}$, Marc Wagner ${ }^{2}$, Benjamin Savenkoff ${ }^{3}$, Mathilde Chastenet de Castaing ${ }^{1}$, Guillaume Desiro ${ }^{1}$, \\ Zead Tubail ${ }^{3}$, Laurent Hennequin ${ }^{4}$, Sinan Ben Mahmoud ${ }^{5}$, Nathalie Marcon ${ }^{6}$, Philippe Quetin', \\ Marco Campitiello ${ }^{1}$ and Francesca Plastino ${ }^{1}$
}

\section{Correction to: BMC Neurol 19, 304 (2019) \\ https://doi.org/10.1186/s12883-019-1542-9}

Following publication of the original article [1], the authors would like to correct the statement under Case presentation, second paragraph.

The sentence currently reads:

"The lumbar ponction revealed a clear pleocytose ( 1 white cell $/ \mathrm{mm} 3 ; \mathrm{NV}<1$ cells $/ \mathrm{mm} 3$ ) and elevated protein levels $(1,15 \mathrm{~g} / \mathrm{L} ; \mathrm{NV}<0,40 \mathrm{~g} / \mathrm{L})$ without any evidence of tumor cells. We documented the presence of serum anti-neuronal Hu antibodies..."

The sentence should read:

"The lumbar ponction did not reveal a pleocytosis (1 white cell $/ \mathrm{mm} 3 ; \mathrm{NV}<1$ cells $/ \mathrm{mm} 3$ ) but elevated protein levels $(1,15 \mathrm{~g} / \mathrm{L} ; \mathrm{NV}<0,40 \mathrm{~g} / \mathrm{L})$ without any evidence of tumor cells. We documented the presence in the serum and in the cerebrospinal fluid (CSF) of anti-neuronal $\mathrm{Hu}$ antibodies..."

The original article [1] has been updated.

\begin{abstract}
Author details
'Division of Medical Oncology, "CHR Metz-Thionville", 1 Allée du Château, 57085 Ars-Laquenexy, France. ${ }^{2}$ Division of Neurology, "CHR Metz-Thionville", 1 Allée du Château, 57085 Ars-Laquenexy, France. ${ }^{3}$ Division of Nephrology, "CHR Metz-Thionville", 1 Allée du Château, 57085 Ars-Laquenexy, France. ${ }^{4}$ Division of Radiology, "CHR Metz-Thionville", 1 Allée du Château, 57085 Ars-Laquenexy, France. ${ }^{5}$ Division of Nuclear Medecine, "CHR Metz-Thionville", 1 Allée du Château, 57085 Ars-Laquenexy, France. ${ }^{6}$ Division of Pathology, "CHR Metz-Thionville", 1 Allée du Château, 57085 Ars-Laquenexy, France. "Division of Radiotherapy, "CHR Metz-Thionville", 1 Allée du Château, 57085 Ars-Laquenexy, France.
\end{abstract}

Published online: 08 March 2022

\section{Reference}

1. Longo R, Wagner M, Savenkoff B, et al. A paraneoplastic limbic encephalitis from an anorectal small cell neuroendocrine carcinoma: a case report. BMC Neurol. 2019;19:304. https://doi.org/10.1186/s12883-019-1542-9. 